\title{
Gas permeability of partially hydrated geosynthetic clay liner under two stress conditions
}

1 M. A. Rouf BSC, MEng

PhD student, Department of Civil Engineering, Monash University, Clayton, Australia

2 R. M. Singh BEng, MTech, PhD Research Fellow, Department of Civil Engineering, Monash University, Clayton, Australia

3 A. Bouazza Civil Ing, PhD, FIEAust Professor, Department of Civil Engineering, Monash University, Clayton, Australia
4 R. K. Rowe BSC, BE, PhD, DEng, FRS, FREng, FRSC, FCAE, FEIC, FIE (Aust), PEng

Professor, Department of Civil Engineering, Queen's University, Kingston, Canada

5 W. P. Gates $\mathrm{BSC}, \mathrm{MSc}, \mathrm{PhD}(\mathrm{Sc})$ Senior Research Fellow, Department of Civil Engineering, Monash University, Clayton, Australia
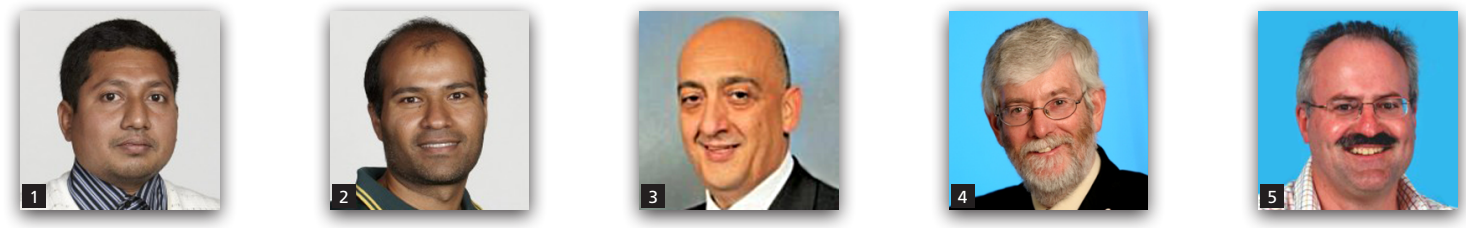

The results of a series of gas permeability tests, with monitoring of gravimetric/volumetric moisture content and total suction, on a commercially available needle-punched geosynthetic clay liner (GCL) are presented. GCL specimens were partially hydrated with deionised water under 2 and $20 \mathrm{kPa}$ confinement prior to testing. The tests were conducted at differential pressures ranging from 1 to $10 \mathrm{kPa}$. Gas permeability was found to decrease with an increase in gravimetric/ volumetric moisture content and a decrease of suction. The effect of the preconditioning stress was found to be more pronounced at gravimetric moisture contents greater than $40 \%$ (25\% apparent degree of saturation, $0.30 \mathrm{~m}^{3} / \mathrm{m}^{3}$ volumetric moisture content), and suctions less than $1.6 \mathrm{MPa}$.

\section{Notation}

A cross-sectional area of the porous material $\left(\mathrm{m}^{2}\right)$

$d \quad$ an average grain diameter of the porous matrix $(\mathrm{m})$

$d P / d x$ pressure gradient $(\mathrm{N} / \mathrm{m})$

$e_{\mathrm{b}} \quad$ bulk void ratio of GCL

$g \quad$ gravitational acceleration $\left(\mathrm{m} / \mathrm{s}^{2}\right)$

$G_{\mathrm{s}} \quad$ specific gravity of the bentonite

$H_{\mathrm{GCL}} \quad$ hydrated GCL thickness (m)

$H_{\mathrm{s}} \quad$ height/thickness of the solids, which includes both bentonite and geotextiles (m)

$K \quad$ gas permeability $\left(\mathrm{m} / \mathrm{s}^{1}\right)$

$k \quad$ intrinsic permeability of the porous material $\left(\mathrm{m}^{2}\right)$

$L \quad$ length of specimen (m)

$M_{\text {bent }} \quad$ dry mass per unit area of bentonite $\left(\mathrm{kg} / \mathrm{m}^{2}\right)$

$M_{\mathrm{GT}} \quad$ mass per unit area of geotextiles $\left(\mathrm{kg} / \mathrm{m}^{2}\right)$

$P_{1} \quad$ inlet pressure $\left(\mathrm{N} / \mathrm{m}^{2}\right)$

$P_{2} \quad$ outlet pressure which is atmospheric pressure $\left(\mathrm{N} / \mathrm{m}^{2}\right)$

$Q \quad$ one-dimensional volumetric flow rate of gas in porous media $\left(\mathrm{m}^{3} / \mathrm{s}\right)$

Re Reynolds number

$v \quad$ Darcy's velocity $(\mathrm{m} / \mathrm{s})$

$w \quad$ gravimetric moisture content of GCL (\%) $w_{\text {ref }}$ maximum gravimetric moisture content that GCL can reach during hydration (\%)

$\theta \quad$ volumetric water content of GCL (\%)

$\mu \quad$ dynamic viscosity of gas $\left((\mathrm{N} \mathrm{s}) / \mathrm{m}^{2}\right)$

$\rho \quad$ density of the $\mathrm{N}_{2}$ gas $\left(\mathrm{kg} / \mathrm{m}^{3}\right)$

$\rho_{\mathrm{gs}} \quad$ density of geotextiles $\left(\mathrm{kg} / \mathrm{m}^{3}\right)$

$\rho_{\mathrm{s}} \quad$ density of bentonite $\left(\mathrm{kg} / \mathrm{m}^{3}\right)$

$v \quad$ kinematic viscosity of the gas $\left(\mathrm{m}^{2} / \mathrm{s}^{1}\right)$

\section{Introduction}

Geosynthetic clay liners (GCLs) are most typically comprised of a thin layer of bentonite contained between two layers of geotextile with the components being held together by needle punching or stitch bonding. They are widely used in final cover systems of modern landfills to minimise migration of gases and infiltration of meteoric water. In this respect, there is a wide body of work available on their hydraulic performance in the context of landfill covers (Benson and Meer, 2009; Benson et al., 2007; Bouazza, 2002; Buckley et al., 2012; Hosney and Rowe, 2013, 2014; LaGatta et al., 1997; Lin and Benson, 2000; Meer and Benson, 2007; Rowe, 2014; Rowe and Hosney, 2013; Scalia and Benson, 2011). However, experimental measurements of their permeability to gases are 
less widely available, and only recently has information on their advective gas flow performance became available in the context of landfill capping (Abuel-Naga and Bouazza, 2009; Bouazza and Vangpaisal, 2003, 2004, 2006, 2007; Bouazza et al., 2008; Didier et al., 2000; Mendes et al., 2010; Pitanga et al., 2011; Vangpaisal and Bouazza, 2004).

For the GCL to efficiently minimise gas flow, its bentonite component must be sufficiently hydrated (Vangpaisal and Bouazza, 2004). Earlier work has shown that the gas permeability of GCLs varied largely with changes in gravimetric moisture content as well as the form of bentonite (powdered or granular) used and indicated that very large attenuation of gas migration could occur if the GCL was sufficiently hydrated (Bouazza and Vangpaisal, 2003; Didier et al., 2000; Pitanga et al., 2011; Vangpaisal and Bouazza, 2004). More importantly, it was also reported that when a GCL lost the absorbed water, its gas permeability significantly increased because of shrinkage of the bentonite component and, in extreme cases, because of the formation of desiccation cracks that provided preferential gas flow paths (Bouazza et al., 2006; Mendes et al., 2010).

The initial as-manufactured state of the bentonite within the GCL when installed at a gravimetric moisture content of 7-12\% is insufficient for the GCL to attenuate gas flow. Generally, it is expected that passive hydration will begin at the time of installation and should be complete prior to significant contact with gas (Anderson et al., 2012; Rayhani et al., 2011). However, there is no guarantee that the GCL will reach full hydration (Buckley et al., 2012; Meer and Benson, 2007), and the potential for the GCL to be unsaturated when needed to control gas migration requires consideration. This highlights the need to quantify the water retention curve of GCLs and its effect on gas permeability.

The objective of this paper is to examine the gas permeability of a needle-punched GCL that was partially hydrated to cover a range of gravimetric moisture contents and suctions under two different curing conditions. The differences in gas flow parameters were identified in relation to the GCL gravimetric moisture content, volumetric moisture content, suction, applied stress and differential gas pressure during measurements.

\section{Mechanism of gas transport}

The movement of gas in porous media such as soil or GCLs is mainly governed by two transport mechanisms: advective flow and diffusive flow. In advective flow, the gas moves in response to a gradient in total pressure. To equalise pressure, a mass of gas travels from a region of higher pressure to a lower one. In the context of landfills, the primary driving force for gas migration, especially through cover systems, is a pressure differential due to natural fluctuations in atmospheric pressure (Vangpaisal and Bouazza, 2004). Other factors that contribute to the pressure differential are changes in the leachate/water table or temperature (Vangpaisal and Bouazza, 2004). Gas movement by diffusion occurs because of molecular interactions and mass flow (Allaire et al., 2008). When a gas is more concentrated in one region of a mixture than another, gas diffuses into the less concentrated region. Thus, the molecules move in response to a partial pressure, or gas concentration, gradient. The present paper will focus only on gas transport due to advective flow caused by a pressure gradient.

Earlier work by Alzaydi et al. (1978), Bouazza and Vangpaisal (2003) and Vangpaisal and Bouazza (2004) showed that Darcy's law could provide a fair approximation of advective gas flow in a lowpermeability material. Furthermore, Massmann (1989) indicated that a groundwater flow model provides a good approximation for gas advection up to a differential pressure of $50 \mathrm{kPa}$.

Based on Darcy's law, the 1D volumetric flow rate $Q\left(\mathrm{~m}^{3} / \mathrm{s}\right)$ of gas in porous media is given as:

1. $Q=-\frac{k}{\mu} A \frac{d P}{d x}$

where $k$ is the intrinsic permeability of the porous material $\left(\mathrm{m}^{2}\right)$; $A$ is the cross-section of the porous material $\left(\mathrm{m}^{2}\right) ; d P / d x$ is the pressure gradient; and $\mu$ is the dynamic viscosity of gas $\left((\mathrm{N} \mathrm{s}) / \mathrm{m}^{2}\right)$. Intrinsic permeability is considered a property of porous material that is independent of permeating gas.

The gas permeability, $K\left(\mathrm{~m} / \mathrm{s}^{1}\right)$, can be calculated from the equation as shown below:

2. $K=\frac{\rho g}{\mu} k$

where $\rho$ is the density of the gas $\left(\mathrm{kg} / \mathrm{m}^{3}\right)$ and $g$ is the gravitational acceleration $\left(\mathrm{m} / \mathrm{s}^{2}\right)$.

Assuming that landfill gas behaves as an ideal gas and that the continuity equation for a gas applies, then Equation 1 becomes

3. $P Q d x=-\frac{k}{\mu} A P d P$

For a specimen of length $L(\mathrm{~m})$, Equation 3 may be integrated subjected to boundary conditions, $P=P_{1}$ at $x=0$ and $P=P_{2}$ at $x=$ $L$, where $P_{2}$ is the atmospheric pressure, to give the mass flow rate entering the atmosphere $\left(Q_{2}\right)$, in terms of boundary pressure, viz:

4. $Q_{2}=\frac{k}{\mu} A \frac{P_{1}^{2}-P_{2}^{2}}{2 P_{2} L}$

It is well established that the application of Darcy's law is only valid when the flow is laminar. The Reynolds number ( $R e)$ is a dimensionless number that expresses the ratio of inertial to viscous 
forces and is generally used as a criterion to distinguish between laminar flow and turbulent flow. The flow rate at which the gas flow begins to deviate from the Darcy's law behaviour is observed when the Reynolds number exceeds a value between 1 and 10 (Bear, 1972). The Reynolds number for flow through porous matrix is defined as

$$
\text { 5. } \quad \operatorname{Re}=\frac{\rho v d}{\mu}=\frac{v d}{v}
$$

where $v$ is the Darcy velocity, $d$ is an average grain diameter of the porous matrix, and $v$ denotes the kinematic viscosity of the gas $(v=\mu / \rho)$.

\section{Materials and methods}

\section{Geosynthetic clay liner}

The commercially available GCL examined in the present investigation was composed of powdered sodium bentonite sandwiched between a needle-punched non-woven geotextile (NW) cover layer and a non-woven geotextile reinforced by a slit film woven geotextile $(\mathrm{NW}+\mathrm{W})$ carrier with the system being needle punched together and thermally treated to provide confinement of the bentonite during transport and placement. The mass of bentonite $\left(M_{\text {bent }}\right)$ was calculated from the difference between the mass per unit area of the GCL and the mass per unit area of the geotextiles $\left(M_{\text {bent }}=\right.$ $\left.M_{\mathrm{GCL}}-M_{\mathrm{GT}}\right) . M_{\mathrm{GCL}}$ was obtained following the procedure outlined in ASTM D5993; the mass per unit area of the geotextiles $\left(M_{\mathrm{GT}}\right)$ was also measured in the laboratory according to ASTM D5261. The mass per unit area of GCL and dry bentonite varied from 4.5 to $5 \cdot 8 \mathrm{~kg} / \mathrm{m}^{2}$ and $3 \cdot 3$ to $4 \cdot 7 \mathrm{~kg} / \mathrm{m}^{2}$, respectively. The GCL physical characteristics and its bentonite properties are shown in Tables 1 and 2 , respectively.

\section{Parameters}

\begin{tabular}{lc}
\hline Bentonite type & Na powder (Trugel) \\
Bonding & Needle punched \\
Cover geotextile & Nonwoven \\
Carrier geotextile & Nonwoven + woven \\
$M_{G C L}: \mathrm{kg} / \mathrm{m}^{2 a}$ & $4 \cdot 5-5 \cdot 8$ \\
$M_{\text {bent }}: \mathrm{kg} / \mathrm{m}^{2}$ & $3 \cdot 3-4 \cdot 7$ \\
$M_{\text {cover: }} \mathrm{kg} / \mathrm{m}^{2 a}$ & $0 \cdot 35$ \\
$M_{\text {carrier }}: \mathrm{kg} / \mathrm{m}^{2 a}$ & $0 \cdot 57$ \\
$H_{G C L}$ as received: $\mathrm{mm}^{\text {a }}$ & $7 \cdot 7-8 \cdot 9$ \\
Moisture content as received $(\%)^{\text {a }}$ & $7-12$ \\
\hline
\end{tabular}

aValues measured at the Monash University laboratory

Table 1. Characteristics of geosynthetic clay liner used in this study

\begin{tabular}{lc} 
Parameters \\
\hline Particle density: g/cm³ \\
Liquid limit: \% & $2 \cdot 65$ \\
Plastic limit: \% & 510 \\
Plasticity index: \% & 45 \\
Swell index: $\mathrm{ml} / 2 \mathrm{~g}$ & 465 \\
\end{tabular}

Table 2. Bentonite properties of $\mathrm{GCL}$

\section{Sample preparation}

GCL specimens were prepared and hydrated to cover a range of various moisture contents and suction values. First, $125 \mathrm{~mm}$ dia. GCL specimens were cut using a sharp knife and a plastic disc as a cutting base. One specimen from each GCL sheet was used to measure initial thickness, mass and moisture content, respectively. Then, the specimens were placed on a saturated porous sponge material to uptake moisture for different specified time periods (bottom-up hydration process). Once the target time was reached, the specimens were removed from the moisture uptake set-up and stored in a double resealable plastic bag for hydration/moisture equilibration. The moisture equilibration of the specimen took place gradually until all available water was absorbed by the bentonite as dry bentonite has a very high negative water potential. For this reason, the equilibration of GCL after moisture uptake was essential. The specimens were hydrated/equilibrated following two different methods. In the first method, the GCL was kept under a normal stress of $20 \mathrm{kPa}$ by direct loading, to simulate the weight of 1-m-thick soil cover in a landfill cover system. In the second method, the GCL was placed under $2 \mathrm{kPa}$ confinement to provide a minimum stress just to ensure uniform distribution of moisture content in the specimen. An equilibration period of 7-10 days was deemed sufficient to homogenise the moisture content of the bentonite component after hydration (Vangpaisal and Bouazza, 2004). An equilibration period of at least 10 days was used in the present investigation to ensure a uniform distribution of moisture in the GCL specimens prior to the gas permeability tests.

\section{Apparatus and test procedures Gas permeability}

The GCL gas permeability cell was designed and developed by Bouazza and Vangpaisal (2003). The cell consisted of two distinct parts: a base cylinder and an upper cylinder with piston (Figure 1). The two parts were held together with threaded retaining rods. The purpose of the piston situated in the upper cylinder was to transmit the applied confining stress to the GCL specimen. The connections of the upper and the base cylinders, and the piston were sealed using O-rings. The base cylinder has two different inside diameters. The upper part has a diameter of $130 \mathrm{~mm}$ and the lower part has a diameter of $100 \mathrm{~mm}$, creating a shoulder on its wall. This shoulder was used to accommodate the GCL specimen and the upper cylinder. The effective gas flow area of the gas permeability cell was $7.85 \times 10^{-3} \mathrm{~m}^{2}$. Nitrogen gas $\left(\mu=1.76 \times 10^{-5}(\mathrm{~N} \mathrm{~s}) / \mathrm{m}^{2}, \rho=\right.$ $1 \cdot 165 \mathrm{~kg} / \mathrm{m}^{3}$ at $20^{\circ} \mathrm{C}$ and atmospheric pressure) was used in as the 


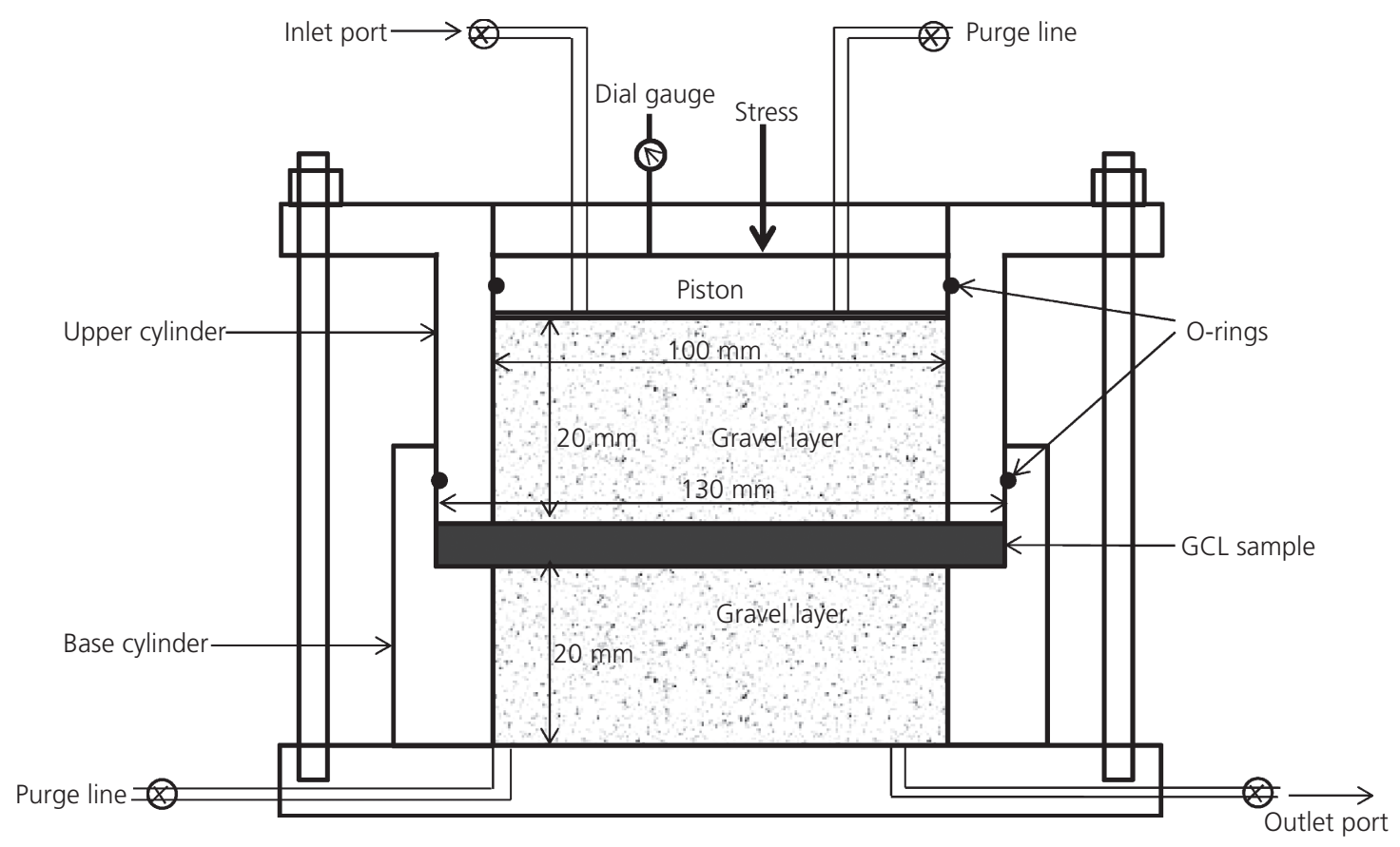

Figure 1. Cross-section of gas permeability cell (modified from

Bouazza and Vangpaisal, 2003; not drawn to scale)

permeating gas because it is relatively inert and has very low water solubility.

To measure gas permeability, nitrogen gas was supplied to the top of the cell, which permeated through the GCL specimen and flowed out from the base of the cell by way of a gas flow meter. Five gas flow meters (GFM17 Mass Flow Meters, Aalborg, Denmark; accuracy: $1.5 \%$ of full range at $20^{\circ} \mathrm{C}$ and atmospheric pressure), having flow rates ranging from 0 to $10 \mathrm{~mL} / \mathrm{min}$ up to $0-15 \mathrm{~L} / \mathrm{min}$, were used alternatively to cover the different gas flow rates. The outflow port was connected to atmospheric pressure. The differential gas pressure was estimated from the difference between the pressure supply and atmospheric pressure.

Placing the GCL specimen in the cell involved several steps. First, a filter paper was placed on the bottom part of the lower chamber to prevent migration of small particles of gravel into the drainage port. Second, 8-mm passing uniform gravel was added to reach a height equal to that of the inner lower chamber and carefully levelled to provide a smooth surface. Third, a 125-mm-dia. hydrated GCL specimen was placed on the gravel layer and on the shoulder of the base cylinder. The gap between the edge of the GCL and the cylinder wall was filled with a bentonite paste similar to the bentonite used in the GCL to minimise sidewall leakage. Fourth, the upper chamber was gently fitted and secured to the base chamber by tightening the retaining rods. The same bentonite paste was also smeared onto the perimeter of the geotextiles and on the upper and lower grooves to complete the lateral sealing at the interface between the two chambers of the cell. Fifth, 8-mm passing uniform gravel was placed over the GCL specimen until the required height $(20 \mathrm{~mm})$ was reached. Sixth, the piston was placed above the gravel layer. After completing the assembling process, the cell was placed on a stand equipped with a load hanger system and a normal stress of either 2 or $20 \mathrm{kPa}$ was applied on the sample. Finally, pressurised nitrogen gas was supplied to the system from the top port of the piston; the applied gas passed through the GCL specimen and vented out through the flow meter to the atmosphere. Gas flow rate, differential pressure, ambient room temperature, and atmospheric pressure were recorded periodically. After completion of the test, the GCL specimen was taken out of the cell and visually inspected for the presence of leakage spots, if any. Final GCL height and gravimetric moisture content was then determined for post-test analyses. The pressure drop across the filter paper and gravel layers was negligible $(<0.02 \mathrm{kPa}$ for sand layers; Bouazza and Vangpaisal, 2003) compared with applied pressure used for gas permeability measurement. It was also observed that under stress conditions, the GCL vertical deformation/volume change was insignificant as the specimen was preconditioned under 2 or $20 \mathrm{kPa}$ during the equilibration process for at least 10 days prior to its placement in the cell. The volume change during unloading was also found to be negligible because of the permanent deformation of the GCL specimen. A full description of the cell and testing procedures are given in Bouazza and Vangpaisal (2003) and Vangpaisal and Bouazza (2004).

\section{Suction measurements}

Total suction measurements were conducted in a dew point potentiometer, referred to herein as WP4C (Decagon Devices, USA). The WP4C uses the chilled-mirror dew point technique to measure 
the total suction/water potential of a GCL specimen. The specimen was equilibrated with the headspace of a sealed chamber that contains a mirror and a system of detecting condensation on the mirror. When equilibrium is reached, the water potential of the air in the chamber will be the same as the water potential of the specimen. In the WP4C, the mirror temperature is precisely controlled by a thermoelectric cooler and detection of the exact first condensation point to appear on the mirror is observed with a photoelectric cell. When a specimen is tested, a beam of light is directed onto the mirror and reflected into a photo detector, which senses the change in reflectance at the time of condensation on the mirror. A thermocouple attached to the mirror then records the temperature at which condensation occurs. One limitation of the WP4C is its inability to allow application of loads on the specimen. The water potential range of WP4C is 0 to $-300 \mathrm{MPa}$ and accuracy is $\pm 0.05 \mathrm{MPa}$ from 0 to $-5 \mathrm{MPa}$ and $1 \%$ from -5 to $-300 \mathrm{MPa}$. In this investigation, three GCL samples (30 mm dia.) were used for total suction measurements. These samples were cut from the GCL specimen (125 mm dia.) at the completion of each gas permeability test. As indicated earlier, no stress was applied to the samples during the measurements of total suction. However, the samples were subjected to two different stress ( 2 and $20 \mathrm{kPa}$, respectively) conditions during the hydration/equilibration process and gas permeability tests.

\section{Results and discussion}

The GCL specimens were hydrated to cover a range of gravimetric moisture contents and suctions within the range that could be monitored with the WP4C. The viscosity and density of the nitrogen gas were considered to be constant as all the tests were conducted in a temperature-controlled room $\left(20 \pm 1^{\circ} \mathrm{C}\right)$.

In case of gas advective flow through porous media, application of Darcy's law (Equation 4) shows that flow rate is proportional to $P_{1}^{2}-P_{2}^{2}$ instead of $\Delta P$ as discussed in Bouazza and Vangpaisal (2003). The gas flow rate at low gravimetric moisture content $(7 \%$ and $13 \%$ ) with corresponding high suction ( 82 and $44 \mathrm{MPa}$ ) and high gravimetric moisture content $(85 \%$ and $68 \%)$ with corresponding low suction $(0.84$ and $1.31 \mathrm{MPa})$ were plotted against $P_{1}{ }^{2}-P_{2}{ }^{2}$ in Figure 2 both under 2 and $20 \mathrm{kPa}$ curing stress conditions. The gas flow rate varied linearly with $P_{1}{ }^{2}-P_{2}{ }^{2}$ for GCL specimens prepared at low gravimetric moisture content and high suction under both stress conditions. Similarly, gas flow rate was estimated to vary linearly with $P_{1}{ }^{2}-P_{2}{ }^{2}$ at high gravimetric moisture content and low

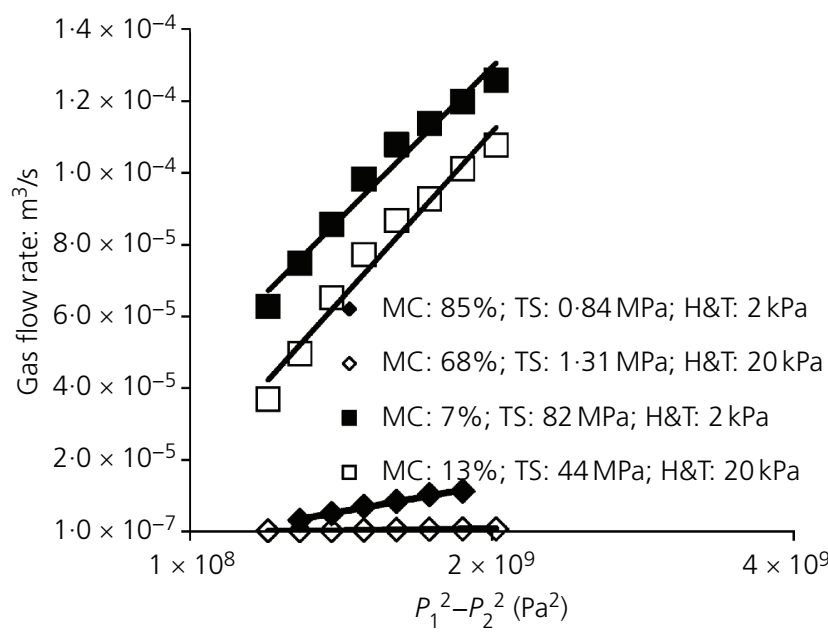

Figure 2. Gas flow rate with $P_{1}^{2}-P_{2}^{2}$ both at low and high moisture content under 2- and 20-kPa stress conditions (MC, gravimetric moisture content; TS, total suction; H\&T, hydration and testing)

suction condition for the two stress conditions investigated in this study. A linear behaviour indicates that gas flow was laminar during the experiments. It was also observed that gas flow rate increased with the decrease of the initial gravimetric moisture content and increase of suction for both stress conditions, indicating that airfilled pores increased with the decrease of gravimetric moisture content irrespective of curing stress difference. However, at high gravimetric moisture content condition, Figure 2 shows that stress governs the gas flow rate. The higher the stress, the lower is the gas flow rate. Reynolds number (Re) estimated in the present study (Table 3), for both wet and dry conditions, was within the range given by Bear (1972). Therefore, it can be inferred that Darcy's law is applicable in this study.

The intrinsic permeability calculated using Equation 4 is plotted in Figure 3 with respect to both increase and decrease of differential pressures for both 2 and $20 \mathrm{kPa}$ stressed specimens at two different gravimetric moisture contents together with their corresponding suctions. The differential gas pressure, for most of the tests, was restricted to the range of $3-10 \mathrm{kPa}$ because the build-up of gas pressure under landfill cover systems is unlikely to be higher than $10 \mathrm{kPa}$ (McBean et al., 1995). Figure 3 shows that the intrinsic

\begin{tabular}{lccccc}
\hline $\begin{array}{l}\text { GCL moisture } \\
\text { content: \% }\end{array}$ & $\begin{array}{c}\text { Hydration and } \\
\text { test stress: kPa }\end{array}$ & $\begin{array}{c}\text { Average } \\
\text { grain size: } \mathrm{m}\end{array}$ & $\begin{array}{c}\text { Gas flow } \\
\text { rate: } \mathrm{m}^{3} / \mathrm{s}\end{array}$ & $\begin{array}{c}\text { Flow } \\
\text { velocity: m/s }\end{array}$ & $\begin{array}{c}\text { Reynolds } \\
\text { number }\end{array}$ \\
\hline 7 & 2 & $5 \times 10^{-6}$ & $1.26 \times 10^{-4}$ & $1.60 \times 10^{-2}$ & $5.23 \times 10^{-3}$ \\
13 & 20 & $5 \times 10^{-6}$ & $1.08 \times 10^{-4}$ & $1.38 \times 10^{-2}$ & $4.51 \times 10^{-3}$ \\
85 & 2 & $5 \times 10^{-6}$ & $1.08 \times 10^{-5}$ & $1.38 \times 10^{-3}$ & $4.51 \times 10^{-4}$ \\
68 & 20 & $5 \times 10^{-6}$ & $8.50 \times 10^{-7}$ & $1.08 \times 10^{-4}$ & $3.53 \times 10^{-5}$
\end{tabular}

Table 3. Estimated Reynolds number for used GCL 
Gas permeability of partially hydrated geosynthetic clay liner under two stress conditions

Rouf, Singh, Bouazza, Rowe and Gates

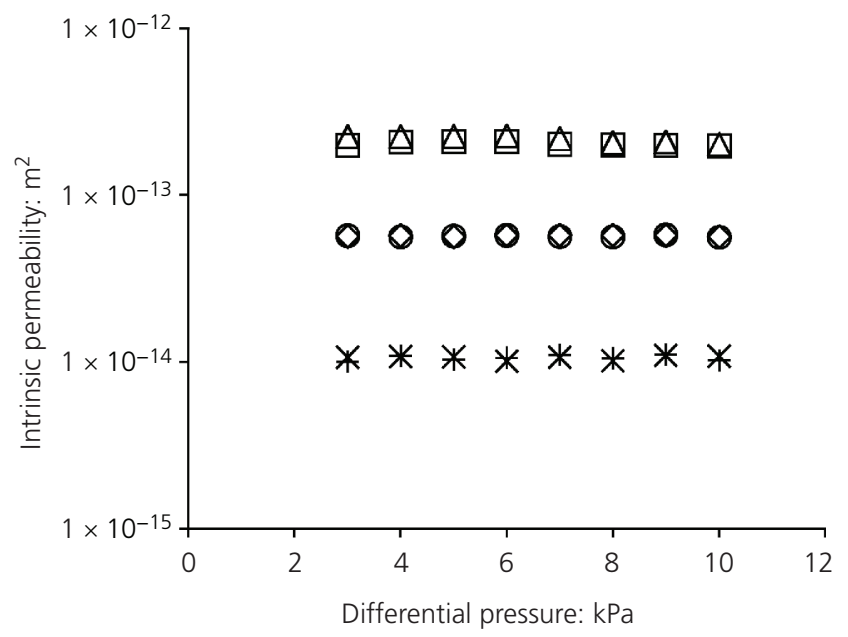

$\Delta$ Increasing (MC: $13 \%$, TS: $44 \mathrm{MPa}, \mathrm{H} \& \mathrm{~T}: 20 \mathrm{kPa}$ )

口Decreasing (MC: 13\%, TS: 44 MPa, H\&T: $20 \mathrm{kPa}$ )

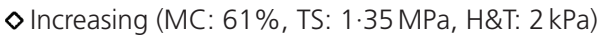

o Decreasing (MC: $61 \%$, TS: $1.35 \mathrm{MPa}, \mathrm{H} \& \mathrm{~T}: 2 \mathrm{kPa}$ )

$\times$ Increasing (MC: $61 \%, \mathrm{TS}: 1.35 \mathrm{MPa}, \mathrm{H} \& \mathrm{~T}: 20 \mathrm{kPa}$ )

+ Decreasing (MC: $61 \%, \mathrm{TS}: 1 \cdot 35 \mathrm{MPa}, \mathrm{H} \& \mathrm{~T}: 20 \mathrm{kPa}$ )

Figure 3. Intrinsic gas permeability against differential pressure for both 2- and 20-kPa stress (MC, gravimetric moisture content; TS, total suction; H\&T, hydration and testing)

gas permeability remained constant over the range of differential pressure used in this investigation. It did not change during increase of pressure from 3 to $10 \mathrm{kPa}$ or decrease of pressure from 10 to $3 \mathrm{kPa}$ suggesting a good repeatability in the measurements. It is also observed that the intrinsic gas permeability increased with the increase of suction (from 1.35 to $44 \mathrm{MPa}$ ) and decrease of gravimetric moisture content (from $61 \%$ to $13 \%$ ). In addition, Figure 3 shows that at the same gravimetric moisture content and suction, the 2-kPa stressed specimen recorded higher intrinsic permeability compared with the $20-\mathrm{kPa}$ stressed specimen because of probable reduction of air-filled pores in the high-stressed specimen.

Figure 4 shows the GCL water retention curve under a wetting path for GCL specimens cured under 2 and $20 \mathrm{kPa}$, respectively, prior to the water retention tests. The GCL total suction varied approximately from $0 \cdot 5$ to $140 \mathrm{MPa}$ and the corresponding gravimetric moisture content was in the range of 5-90\%. The GCL water retention curve exhibited typical trend for fine-grained soil both under 2 and $20 \mathrm{kPa}$ curing stress. A small change in the total suction (from 0.85 to $3 \mathrm{MPa}$ ) was associated with a large and rapid decrease in moisture content because of air entering the GCL specimen. Beyond $3 \mathrm{MPa}$ suction, there was a large increase in suction with only a small decrease in gravimetric moisture content. Over the range of water content examined, the preconditioning stresses of 2 and $20 \mathrm{kPa}$ had no major effect on the variation of the water retention curve. This may be due to the cutting of small samples from a large specimen and the absence of applied stress during the measurement of total suction, which allowed the GCL samples to partially regain their 330

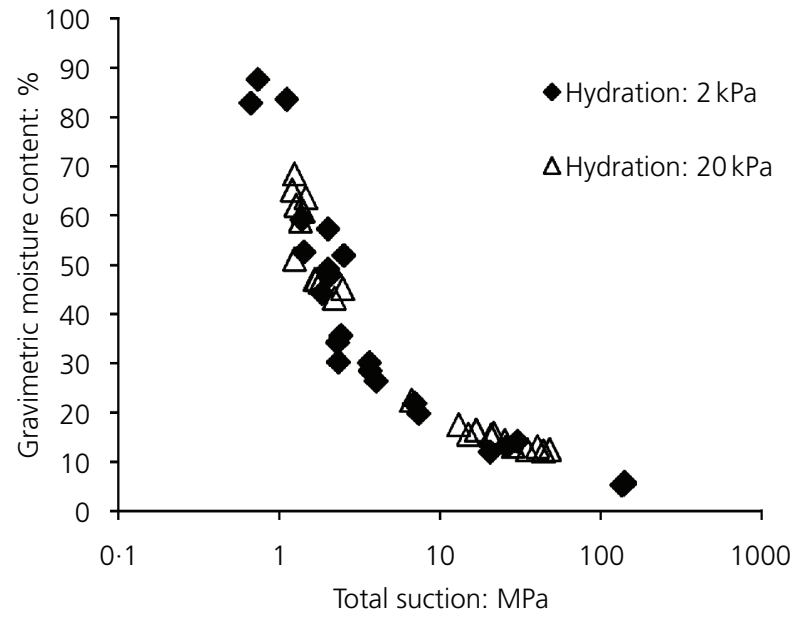

Figure 4. GCL water retention curve on the wetting path

original condition. This needs further investigation before a firm conclusion can be reached.

Anderson et al. (2012), Rayhani et al. (2011) and Singh and Bouazza (2013) defined the apparent degree of saturation as the gravimetric moisture content $(w)$ of a GCL (both geotextile and bentonite contribution) at a given time divided by the maximum gravimetric moisture content $\left(w_{\text {ref }}\right)$ that the same GCL can reach during hydration under the same applied stress conditions. Figure 5 indicates that $w_{\text {ref }}$ under $2-\mathrm{kPa}$ (50 days hydration) and $20-\mathrm{kPa}$ (90 days hydration) stressed specimens were $168 \%$ and $163 \%$, respectively. In the present investigation, the apparent degree of saturation $\left(w / w_{\text {ref }}\right)$ for low gravimetric moisture content specimens was $4 \%(w=7 \%)$ and $8 \%(w=13 \%)$, respectively, under 2 - and $20-\mathrm{kPa}$ stressed

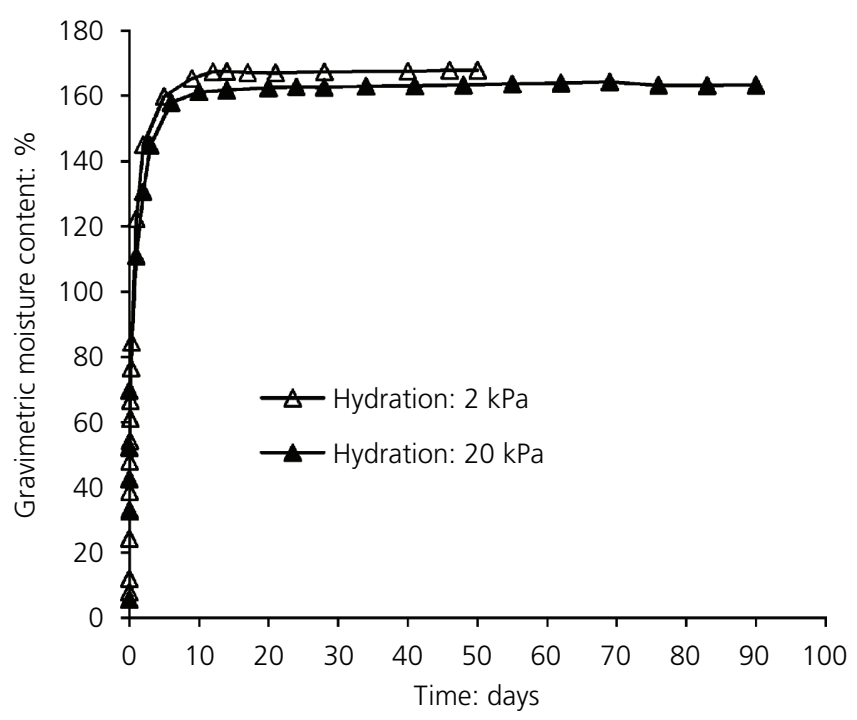

Figure 5. Hydration behaviour of GCL specimen under 2- and 20-kPa stress conditions 
specimens. For high gravimetric moisture content, $w / w_{\text {ref }}$ values were $51 \%(w=85 \%, 2 \mathrm{kPa})$ and $42 \%(w=68 \%, 20 \mathrm{kPa})$.

The estimated gas permeability was plotted against gravimetric moisture content, apparent degree of saturation (Figure 6(a)) and total suction (Figure 6(b)) for both 2- and 20-kPa stresses. It is to be noted that GCL specimens were subjected to these stresses during the hydration process and the gas permeability tests. In addition, data from Vangpaisal and Bouazza (2004) were included in Figure 6(a) for comparative purposes. Vangpaisal and Bouazza (2004) used thermally treated GCL, similar to the material used in the present study, referred to as GCL-1 in their research to measure gas permeability under $20-\mathrm{kPa}$ confinement conditions.

Figure 6(a) shows that gas permeability decreased with the increase of gravimetric moisture content $(w)$ and apparent degree of saturation $\left(w / w_{\text {ref }}\right)$ for both stresses. It can also be observed that gas permeability decreased by one order of magnitude due to gravimetric moisture content increasing from $7 \%\left(w / w_{\text {ref }}=4 \%\right)$ to $85 \%\left(w / w_{\text {ref }}=50 \%\right)$ at $2 \mathrm{kPa}$; while at $20-\mathrm{kPa}$ stress, gas permeability decreased a little bit more than two orders of magnitude because of gravimetric moisture content increase of approximately $50 \%$ and apparent degree of saturation increase of approximately $35 \%$. In Figure 6(a), it is also found that the GCL-1 data from Vangpaisal and Bouazza (2004) agreed well with the current measured gas permeability for specimens tested under the same conditions. Up to $40 \%$ gravimetric moisture content and $25 \%$ apparent degree of saturation, no marked difference was observed in the gas permeability values for the conditions considered in the present investigation. This might be due to the fact that in this range (i.e. $10-40 \%$ moisture), there was insufficient moisture to reduce or block the air-filled pore network of the specimen and minimise gas

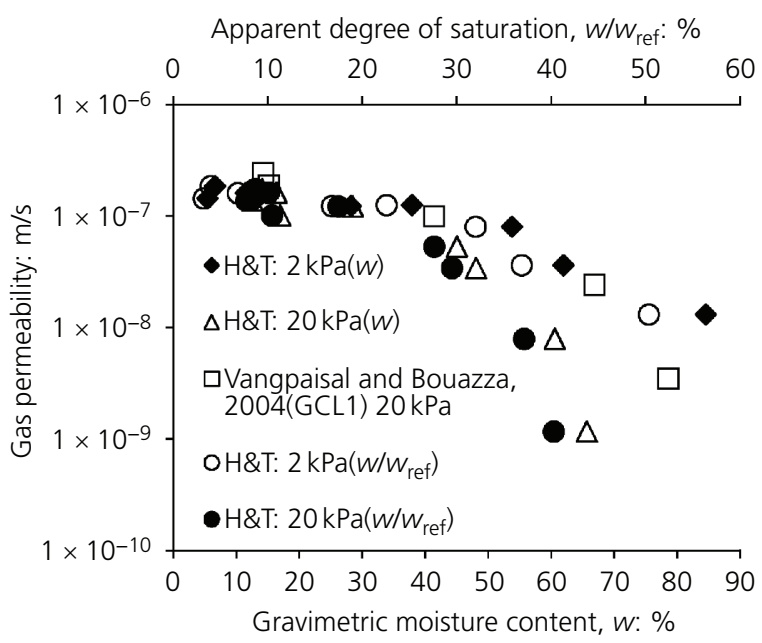

(a)

Figure 6. Gas permeability with respect to (a) gravimetric moisture content, $w$ and apparent degree of saturation, $w / w_{\text {ref, }}$ and (b) total suction under 2- and 20-kPa stress conditions (H\&T, hydration and testing) flow. However, at higher gravimetric moisture content/apparent degree of saturation, a noticeable difference in gas permeability values was observed. The gas permeability reduced by one to two orders of magnitude for specimens hydrated and tested under $20 \mathrm{kPa}$ compared with specimens under $2 \mathrm{kPa}$. This reduction is considered to be due to a much greater reduction of pore space and disruption of the air-filled pore networks at higher stress compared with low-stress specimens. These results imply that, for this GCL, the effect of stress is insignificant up to $40 \%$ gravimetric moisture content and $25 \%$ apparent degree of saturation; beyond this range, gas permeability was greatly affected by stresses.

Figure 6(b) shows that gas permeability increased with the increase of total suction. Under the 2-kPa stress condition, gas permeability increased by one order of magnitude when total suction increased from $0 \cdot 85$ to $140 \mathrm{MPa}$. Similarly, under $20-\mathrm{kPa}$ stress, gas permeability increased more than two orders of magnitude when total suction increased from 1.2 to $88 \mathrm{MPa}$. It was also observed from Figure 6 (b) that at low suction (suction less than 1.6 MPa) gas permeability increased at low stress compared with high stress. However, at suction higher than $1.6 \mathrm{MPa}$, there was no noticeable difference in gas permeability for both 2 - and $20-\mathrm{kPa}$ stress conditions. This result indicates that the pore structure of the GCL specimens changed at low suction conditions under the two different stresses.

Bulk void ratio of a porous media is the ratio of the bulk volume of voids to volume of solids in hydrated GCL and can be calculated based on Petrov and Rowe (1997), as follows:

6. $e_{\mathrm{b}}=\frac{H_{\mathrm{GCL}}-H_{\mathrm{s}}}{H_{\mathrm{s}}}$

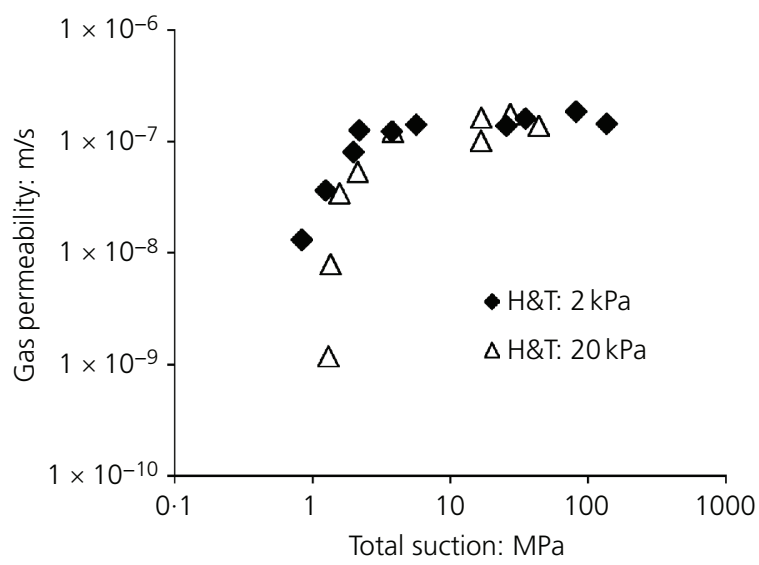

(b) 
Gas permeability of partially hydrated geosynthetic clay liner under two stress conditions

Rouf, Singh, Bouazza, Rowe and Gates
7. $H_{\mathrm{s}}=\frac{M_{\mathrm{bent}}}{\rho_{\mathrm{s}}}+\frac{M_{\mathrm{GT}}}{\rho_{\mathrm{gs}}}$

where $H_{\mathrm{GCL}}$ is the hydrated GCL weight, $H_{\mathrm{s}}$ is the height of the solids (bentonite and geotextiles), $M_{\mathrm{bent}}$ is the dry mass per unit area of bentonite, $M_{\mathrm{GT}}$ is the mass per unit area of geotextiles, $\rho_{\mathrm{s}}$ is the density of bentonite and $\rho_{\mathrm{gs}}$ is the density of geotextiles.

Volumetric moisture content of the GCL sample is given by

8. $\theta=\frac{w G_{\mathrm{s}}}{1+e_{\mathrm{b}}}$

where $w$ is the gravimetric moisture content and $G_{\mathrm{s}}$ is the specific gravity of the bentonite.

The variation of gas permeability was plotted against volumetric moisture content in Figure 7. The gas permeability results with respect to volumetric moisture content showed a similar trend to the variation against gravimetric moisture content shown in Figure 6(a) for both stresses. Figure 7 also indicates that up to $0 \cdot 3 \mathrm{~m}^{3} / \mathrm{m}^{3}$ volumetric moisture content, no marked difference in gas permeability values was observed for the conditions considered in the present investigation. Actually, in this range (i.e. $\theta<0 \cdot 3 \mathrm{~m}^{3} / \mathrm{m}^{3}$ ), there was insufficient volume of moisture to hydrate the specimens and to cause any change in their pore structure. However, at high volumetric moisture content, a noticeable difference in gas permeability values was observed. The gas permeability reduced by one to two orders of magnitude for the specimens subjected to $20-\mathrm{kPa}$ stress compared with specimens under 2-kPa stress. This

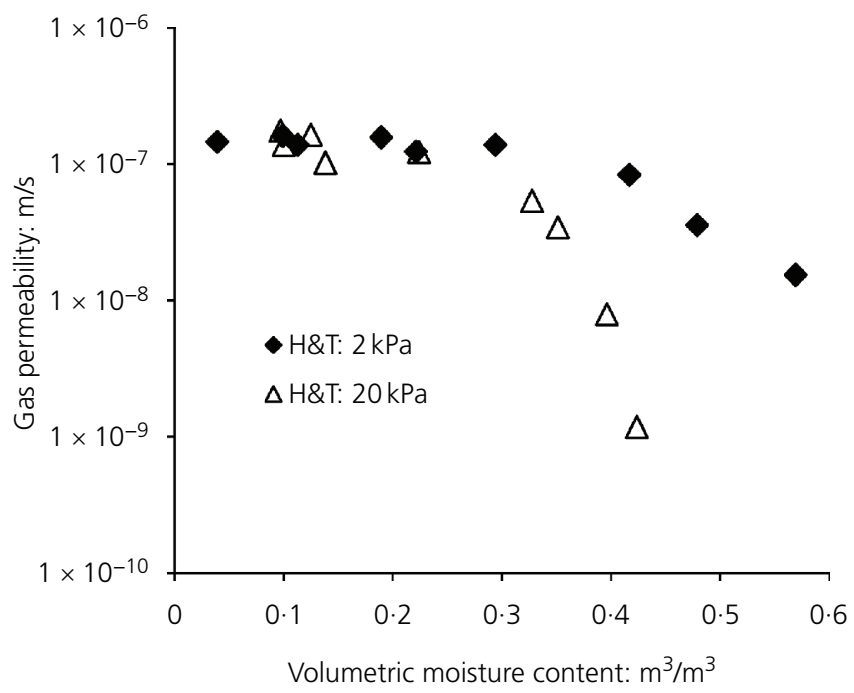

Figure 7. Gas permeability with respect to volumetric moisture content under 2- and 20-kPa stress condition (H\&T, hydration and testing) reduction is considered to be due to a much greater reduction of pore space and increase in the tortuosity of the air-filled pore networks at high-stress condition compared with low-stress condition. These results imply that, for this GCL, the effect of stress is insignificant for up to $30 \%$ volumetric moisture content; beyond this range, gas permeability was greatly affected by preconditioning stresses.

\section{Conclusions}

The gas permeability of the needle-punched GCL examined was greatly influenced by gravimetric moisture content (and hence volumetric moisture content and total suction). The effect of the applied stress (2 or $20 \mathrm{kPa}$ ) was insignificant at low gravimetric $(<40 \%) /$ volumetric $\left(<0 \cdot 3 \mathrm{~m}^{3} / \mathrm{m}^{3}\right)$ moisture content and corresponding high suction $(>1.6 \mathrm{MPa})$, while the effect of stress became more significant beyond these ranges. These initial findings suggest that, at a nominal overburden pressure of $20 \mathrm{kPa}$, this GCL needs to be hydrated to more than $70 \%$ gravimetric moisture content (40\% apparent degree of saturation) before the gas permeability drops to $1 \times 10^{-9} \mathrm{~m} / \mathrm{s}$ and to an even high water content (degree of saturation) at lower stress. More research is needed to evaluate the level of overburden pressure required to obtain a low gas permeability (i.e. less than $1 \times 10^{-12} \mathrm{~m} / \mathrm{s}$ ); however, these results highlight the importance of ensuring that the subgrade has a water retention curve (grain size distribution) and initial moisture content sufficient to allow adequate hydration (e.g. Anderson et al., 2012; Chevrier et al., 2012; Rayhani et al., 2011; Rowe, 2014; Siemens et al., 2012) before the GCL can act as a gas barrier and for this moisture to be retained in the long term. The relationship between overburden stress, moisture content and gas permeability may depend on the particle size of the bentonite and other GCL characteristics, and these results cannot be assumed to be applicable to GCLs other than the one examined herein without independent verification.

\section{Acknowledgement}

This research was supported under Australian Research Council's Discovery Projects funding scheme (project number: ARC DP110104078).

\section{REFERENCES}

Abuel-Naga HM and Bouazza A (2009) Numerical characterization of advective gas flow through GM/GCL composite liners having a circular defect in the geomembrane. Journal of Geotechnical and Geoenvironmental Engineering 135(11): 1661-1671.

Allaire SE, Lafond JA, Cabral AR and Lange SF (2008) Measurement of gas diffusion through soils: comparison of laboratory methods. Journal of Environmental Monitoring 10: 1326-1336.

Alzaydi AA, Moore CAA and Rai IS (1978) Combined pressure and diffusional transition region flow of gases in porous media. American Institute of Chemical Engineers Journal 24(1): 35-43.

Anderson R, Rayhani MT and Rowe RK (2012) Laboratory investigation of GCL hydration from clayey sand subsoil. Geotextiles and Geomembranes 31: 31-38. 
Bear J (ed) (1972) Dynamics of Fluid in Porous Media. American Elsevier Publishing Company, Dover, New York, USA.

Benson C and Meer SR (2009) Relative abundance of monovalent and divalent cations and the impact of desiccation on geosynthetic clay liners. Journal of Geotechnical and Geoenvironmental Engineering 135(3): 349-358.

Benson C, Thorstad P, Jo H and Rock S (2007) Hydraulic performance of geosynthetic clay liners in a landfill final cover. Journal of Geotechnical and Geoenvironmental Engineering 133(7): 814-827.

Bouazza A (2002) Geosynthetic clay liners. Geotextiles and Geomembranes 20: 3-17.

Bouazza A and Vangpaisal T (2003) An apparatus to measure gas permeability of geosynthetic clay liners. Geotextiles and Geomembranes 21: 85-101.

Bouazza A and Vangpaisal T (2004) Effect of straining on gas advective flow of a needle punched GCL. Geosynthetics International 11(4): 287-295.

Bouazza A and Vangpaisal T (2006) Laboratory investigation of gas leakage rate through a GM/GCL composite liner due to a circular defect in the geomembrane. Geotextiles and Geomembranes 24: 110-115.

Bouazza A and Vangpaisal T (2007) Gas permeability of GCLs: effect of poor distribution of needle punched fibres. Geosynthetics International 14(4): 248-252.

Bouazza A, Vangpaisal T and Jefferis S (2006) Effect of wetdry cycles and cation exchange on gas permeability of geosynthetic clay liners. Journal of Geotechnical and Geoenvironmental Engineering 132(8): 1011-1018.

Bouazza A, Vangpaisal T, Abuel-Naga HM and Kodikara J (2008) Analytical modelling of gas leakage rate through a geosynthetic clay liner-geomembrane composite liner due to a circular defect in the geomembrane. Geotextiles and Geomembranes 26: 122-129.

Buckley J, Gates WP, Daniel T and Gibbs DT (2012) Forensic examination of field GCL performance in landfill capping and mining containment applications. Geotextiles and Geomembranes 33: 7-14.

Chevrier B, Cazaux D, Didier G, Gamet M and Guyonnet D (2012) Influence of subgrade, temperature and confining pressure on GCL hydration. Geotextiles and Geomembranes 33: 1-6.

Didier G, Bouazza A and Cazaux D (2000) Gas permeability of geosynthetic clay liners. Geotextiles and Geomembranes 18: 235-250.

Hosney MS and Rowe RK (2013) Changes in GCL properties after two years in a cover over arsenic-rich tailings. Canadian Geotechnical Journal 50(3): 326-342.

Hosney MS and Rowe RK (2014) Performance of three GCLs used for covering gold mine tailings for 4 years under field and laboratory exposure conditions. Geosynthetics International 21(3): 197-212.

LaGatta MD, Boardman BT, Cooley BH and Daniel DE (1997) Geosynthetic clay liners subjected to differential settlement. Journal of Geotechnical and Geoenvironmental Engineering ASCE 123(5): 402-410.
Lin L and Benson C (2000) Effect of wet-dry cycling on swelling and hydraulic conductivity of GCLs. Journal of Geotechnical and Geoenvironmental Engineering 126(1): 40-49.

Massmann JW (1989) Applying groundwater flow models in vapor extraction system design. Journal of Environmental Engineering ASCE 115(1): 129-149.

McBean EE, Rovers FA and Farquhar GJ (eds) (1995) Solid Waste Landfill: Engineering and Design. Prentice-Hall, Englewood Cliffs, NJ, USA.

Meer S and Benson C (2007) Hydraulic conductivity of geosynthetic clay liners exhumed from landfill final covers. Journal of Geotechnical and Geoenvironmental Engineering 133(5): 550-563.

Mendes MJA, Pierson P, Touze-Foltz N, Mora H and Palmeira EM (2010) Characterisation of permeability to gas of geosynthetic clay liners in unsaturated conditions. Geosynthetics International 17(5): 344-354.

Petrov RJ and Rowe RK (1997) GCL-chemical compatibility by hydraulic conductivity testing and factors impacting its performance. Canadian Geotechnical Journal 34(6): 863-885.

Pitanga HN, Pierson P and Vilar OM (2011) Measurement of gas permeability in geosynthetic clay liners in transient flow mode. Geotechnical Testing Journal 34(1): 27-33.

Rayhani MT, Rowe RK, Brachman RWI, Take WA and Siemens G (2011) Factors affecting GCL hydration under isothermal conditions. Geotextiles and Geomembranes 29(6): 525-533.

Rowe RK (2014) Performance of GCLs in liners for landfill and mining applications. Environmental Geotechnics 1(1): 3-21; http://dx.doi.org/10.1680/envgeo.13.00031.

Rowe RK and Hosney MS (2013) Laboratory investigation of GCL performance for covering arsenic contaminated mine wastes. Geotextiles and Geomembranes 39: 63-77.

Scalia J and Benson CH (2011) Hydraulic conductivity of geosynthetic clay liners exhumed from landfill final covers with composite barriers. Journal of Geotechnical and Geoenvironmental Engineering 137(1): 1-13.

Siemens GA, Take WA, Rowe RK and Brachman RWI (2012) Numerical investigation of transient hydration of unsaturated geosynthetic clay liners. Geosynthetics International 19(3): 232-251.

Singh RM and Bouazza A (2013) Thermal conductivity of geosynthetics. Geotextiles and Geomembranes 39: 1-8.

Vangpaisal T and Bouazza A (2004) Gas permeability of partially hydrated geosynthetic clay liners. Journal of Geotechnical and Geoenvironmental Engineering 130(1): 93-102.

\section{HOW CAN YOU CONTRIBUTE?}

To discuss this paper, please submit up to 500 words to theeditor at journals@ice.org.uk. Your contribution will be forwarded to the author(s) for a reply and, if considered appropriate by the editorial board, it will be published as a discussion in a future issue of the journal. 